\title{
British Association Expedition to the Great Barrier Reef.
}

\author{
By Dr. C. M. Yonge.
}

$\mathrm{M}$ ARINE biology has advanced greatly of recent years. It is becoming quantitative in its methods, beginning to demonstrate cause as well as effect, while, as the result of co-ordinated research by plankton workers and chemists, the full story of the annual cycle of life in the sea is gradually being elucidated. Practically all this work has, however, been done in temperate seas, and the extent to which similar conditions prevail in tropic waters is entirely unknown. Here is a great and open field for the application of modern scientific methods and one in which a rich harvest cannot fail to be reaped. Hitherto, opportunities have been lacking; there are no big marine laboratories in the tropics, while deep-sea expeditions have only been able to make isolated observations.

This long-desired opportunity has at last been provided by the Australian Great Barrier Reef Committee, which two years ago invited Great Britain to send out an expedition to make a thorough biological investigation of the Great Barrier Reef of Australia. The organisation of this expedition was undertaken by the British Association at the recent meeting at Leeds, and a committee, consisting of members of the Sections of Botany, Geography, Geology, and Zoology, to which were later added several Australian representatives, was instituted for this purpose.

If the necessary funds can be raised, the expedition will leave this spring, and work on the reef will be carried on continuously for at least a year. The leader of the expedition will be Dr. C. M. Yonge, Balfour Student in the University of Cambridge. Mr. F. S. Russell, of the Plymouth Marine Biological Laboratory, will be in charge of the plankton investigations and other work of the boat party for the first six months. Mr. Tandy, of the British Museum (Natural History), is expected to be the botanist, concerned especially with the calcareous algæ; and the Royal Geographical Society is considering how best to provide the services of a surveyor for the expedition. The full plan also includes a chemist and hydrographer, who will study the chemical and physical conditions of the sea water, while an experienced zoologist has expressed his willingness to take charge of the reef work. In addition, there is the promise of considerable assistance from the Universities of Brisbane and Sydney, and from the Australian Museum at Sydney; the British Committee lays the greatest stress on this, in view of the continuation of such studies in subsequent years.

With the exception of the work of the geographer, the investigations proposed will be purely biological. The geology of the reef has already received considerable attention from Prof. H. C. Richards, of the University of Brisbane, who has been the prime mover in all recent work on the reef. It is hoped that the surveying ship of H.M. Australian Navy will be able to assist in the accurate surveying and charting of the region where the expedition will work.

The plan of operations may be conveniently summarised under four headings. First, there is work on the reef, and this will include an ecological survey of the corals and their associated organisms, both animal and plant, their food and mode of feeding, their rate of growth, and their seasons of reproduction. Conditions on various parts of the reef, exposed to very different factors, will be compared and correlated with differences found in the plankton and the sea water. This work will be conducted by a 'reef' party of probably two zoologists and the botanist.

Closely connected with the above work will be an examination, as detailed as conditions will allow, of the bottom fauna and flora and the deposits, between the reef and the mainland and, so far as possible, on the outer side of the reef. For this purpose dredges and the Agassiz trawl will be used, and also quantitative grabs and bottom samplers. An important part of this work will be the determination of the zoning of life at increasing depths, information which is urgently needed for the proper working out of the contents of the bores made into reefs.

This work, and that of the third set of investigations, concerned with plankton and sea water, will be carried out from a powerful motor-boat which has been kindly offered, together with a smaller boat for work round the edge of the reef, by the Navy Yard at Sydney. The variations of the plankton-seasonally, diurnally, and at different depths-will be studied by means of samples taken with water-bottles, fine and coarse silk tow - nets, and stramin nets. Mr. Russell, who will have assistants, will employ the methods which have yielded him such excellent results in Great Britain, so that the findings will be directly comparable with those obtained in our temperate seas. A series of stations will be selected for this work, and water samples will be taken at the same time from which accurate determinations of temperature and salinity, of the nitrate, phosphate, silica, calcium, and oxygen content, and of the hydrogen-ion concentration will be made by the chemist. Variations in these will be correlated with variations in the plankton.

The fourth line of research will, it is hoped, tie together all the work into one connected whole. It will consist of a detailed study of the mode of feeding and digestion in the different corals, and of their food throughout the year. The relative extent to which corals depend upon plankton for food or are nourished by the unicellular algæ which live symbiotically in their tissues will be investigated. This is a matter of fundamental importance and one on which our knowledge is extremely scanty. The method of calcium deposition in corals, as a result of which the skeleton is formed, will also be studied.

Finally, the economic possibilities of the reef will

No. 3041, VoL. 121] 
receive thorough attention. At present there is an extensive trade in pearl shell and trochus, in bêche-de-mer and in turtles, and the possibility of increasing these by methods of cultivation and of establishing a sponge fishery-of native or, if feasible, imported sponges-will be examined.
The commercial potentialities of the fisheries will be estimated so far as opportunities permit. The Great Barrier Reef is immensely rich in life and should prove a source of vast wealth if properly exploited, and for this a thorough biological survey is the essential preliminary.

\section{Obituary.}

Mr. R. A. Herman.

CAMBRIDGE mathematicians of the past forty years will have learnt with deep regret of the sudden death of Mr. Herman, of Trinity, on Nov. 29 last, at the age of sixty-six years. Versatile and skilful, Herman devoted to teaching powers that were ample to have made him one of the celebrated mathematicians of his time, and his monument must be sought in the multitude of his pupils who have won distinction for themselves.

Herman took the Tripos in 1882, and was described at the time as the last 'real' Senior Wrangler, for the Tripos was about to be divided, and the title, though surviving until 1909, depended after Herman's year on only the first part, the second part being a postgraduate examination. After gaining in due course a Smith's Prize and a Trinity fellowship, Herman went to Liverpool as professor, but he stayed there only two years, and returned in 1886 to Cambridge, where he spent the rest of his life. He was given the honorary degree of LL.D. at St. Andrews in 1920.

At the time of Herman's return, and until 1909, mathematical teaching in Cambridge was of two kinds : in theory the ground for the Tripos was covered by college lectures, but in practice success depended on the private coach. Herman served a full period of office as a college lecturer, and he was a University lecturer for many years, but it was as a coach that he became famous. Reputation in this field was difficult to acquire, but Herman had a genius for teaching which won its reward when J. E. Wright was Senior Wrangler in 1900 , and from 1903 until 1909 one or more of his pupils, alone or bracketed, headed the list: of the last eleven Senior Wranglers, he coached nine.

For a few years after 1909, force of custom still sent the best scholars to be coached, but the new regulations put the premium on specialisation, and the use which Herman could make of his powers under the changed conditions was still uncertain in 1914. During the War he was engaged on various routine tasks; he lost his only son, reported missing and never heard of again, and suspense and grief affected his subsequent career. After the War he continued to read and to enjoy mathematics, but his diminished energy found sufficient scope in his University lecturing.

Herman was beyond question a great teacher, at once conscientious and inspiring, methodical and brilliant. His revision papers were miracles of thoroughness, and by means of weekly problem papers he imparted all that it was possible to impart of his own facility in the problem-solving that was formerly essential to distinction in Cambridge examinations. As a mathematician he was an artist to the finger-tips, scrupulously rigorous, little satisfied by a mechanical solution, and quick with praise when he saw beauty. There was no branch of Tripos mathematics in which he was not proficient, and there were many subjects in which his knowledge extended far beyond the range of any examination. He was an astronomer in a university where astronomers flourish, his only book was on geometrical optics, and he was an authority on the most difficult problems of discontinuous motion in fluids, but it was to differential geometry as investigated by kinematical methods that he was most devoted.

A teacher's fame is local and ephemeral, but so long as any of Herman's pupils are alive he will be remembered with gratitude and affection.

\section{Mr. J. H. Durrant.}

Through the death at his residence at Putney on Thursday, Jan. 19, of John Hartley Durrant, entomological science loses a worker who has long been known for his extensive knowledge, not only of the Microlepidoptera, but also of entomological literature and matters in general connected with taxonomy and nomenclature. $\mathrm{Mr}$. Durrant was born at Hitchin on Jan. 10, 1863. $\mathrm{He}$ was one of the few remaining fellows of the Entomological Society of London who could date their association with that Society back to 1883 , when he became a member. In 1886 he took charge of the late (the sixth) Lord Walsingham's extensive collection of Microlepidoptera at Merton Hall, Norfolk, and when this collection, which comprised some 260,000 specimens, was transferred, together with the Walsingham entomological library, to the British Museum (Natural History), he became a member of the scientific staff there.

Mr. Durrant was closely associated with the late Lord Walsingham in the preparation of the Microlepidoptera volumes of both the "Fauna Hawaiiensis" and the "Biologia Centrali-Americana," and he was personally responsible for the completion of the latter work after the transfer of the Walsingham library and collections to the British Museum. He was a most careful worker, and one has only to look at the manner in which the extensive synonymies given in the "Biologia" are drawn up, to be impressed by the evidences of painstaking care and sound judgment there exhibited. In an interleaved copy of the volume on the Microlepidoptera of the "Biologia Centrali-Americana," as well as in his note-books, there is also evidence that he was an accomplished artist, many of his sketches

No. 3041, Vor. 121] 